\title{
HIGH ALTITUDE WIND DATA FROM METEOROLOGICAL ROCKETS
}

\author{
LCDR. C. L. ARMSTRONG, USN* and LT. (jg) R. D. GARRETT, USN*
}

[Manuscript received March 29, 1960; revised May 16, 1960]

\begin{abstract}
This paper presents a preliminary summary of results obtained from meteorological rocket firings made by the United States Navy from Point Mugu, Calif., during the fall of 1959 and the winter of 1960.

Although certain problems were encountered during these initial firings, it is felt that the wind data derived is as complete and as reliable as present acquisition, read-out, and instrumentation techniques will permit.

The data compare favorably with those obtained from high-level balloon soundings and tend to support previous ideas on wind flow in the mesosphere.
\end{abstract}

\section{INTRODUCTION}

In the fall of 1959 the Inter-Range Meteorological Working Group (IRMWG) established a Meteorological Rocket Network [1] and initiated a synoptic schedule calling for daily launches during one month of each season. Because of safety and instrumentation considerations, the initial network of stations was limited to six missile ranges. Point Mugu, Calif. (Pacific Missile Range), as one of the participating stations, accomplished regularly scheduled firings in October and November of 1959 and January and February 1960. Although the art of using meteorological rockets, motivated by requirements for winds to very high altitudes, has just begun to be exploited, it is felt that great potential for further progress is evident.

\section{ROCKETS}

Three types of meteorological probes have been used thus far. The ARCAS (all-purpose rocket for the collection of atmospheric soundings) is a single-stage, unguided, solid propellant vehicle with an altitude capability of 210,000 feet. A 15 -ft. metalized parachute (ejected at apogee) serves as a radar target for computing wind drift and also carries a 4- to 5 -lb. instrument package that telemeters temperature data back to a standard GMD rawinsonde station utilizing a $1680 \mathrm{mc}$. transmitter. LOKI I and LOKI II rockets are also unguided, solid propellant vehicles but have a second stage consisting of an unpowered dart. The LOKI I dart contains an 8-ft. mylar parachute while the LOKI II dart usually contains S-band radar chaff. Wind data are obtained by radar

*Assigned to Pacific Missile Range Weather Center, Point Mugu, Calif. The opinions expressed herein are the authors' own and do not necessarily reflect the views of the Navy Department. track of the targets (instrumented darts are not yet available). The LOKI I and LOKI II rockets have altitude capabilities of approximately $110,000 \mathrm{ft}$. and $225,000 \mathrm{ft}$., respectively. A summary of the meteorological rocket firings at Point Mugu, from which data were obtained, is presented in table 1. Tracking support was provided by SCR 584 and FPS-16 radars.

\section{RESULTS}

Figures 1 and 2 are time cross sections depicting wind data obtained during fall and winter respectively. Height in kilometers and thousands of feet is shown on the ordinate and firing days are indicated on the abscissa. The standard wind plotting system $(50 \mathrm{kt}$. per flag, $10 \mathrm{kt}$. per full barb, $5 \mathrm{kt}$. per half barb) is utilized to show wind direction and speed.

It is noteworthy that the rocket observations confirm the polar front jet stream in the upper troposphere and the familiar wind speed minimum above the tropopause near 70,000-80,000 ft. Figure 1 actually reveals a weak zone of easterlies at these levels during late October. Figure 2 shows this same interesting breakdown in the normal westerly flow during early February with a clearly defined easterly maximum occurring on the 1 st and $2 \mathrm{~d}$ at $100,000-110,000 \mathrm{ft}$.

Figure 3 shows the mean zonal winds plotted against altitude using data obtained from both the fall and winter series. This graph is quite interesting in that it shows the rapid increase of the zonal westerlies in the mesosphere. In spite of the fact that no corrections have been applied for wind response delay at target deployment, the mesospheric maximum is apparently located near the average peak altitude being achieved by the rockets. The few 


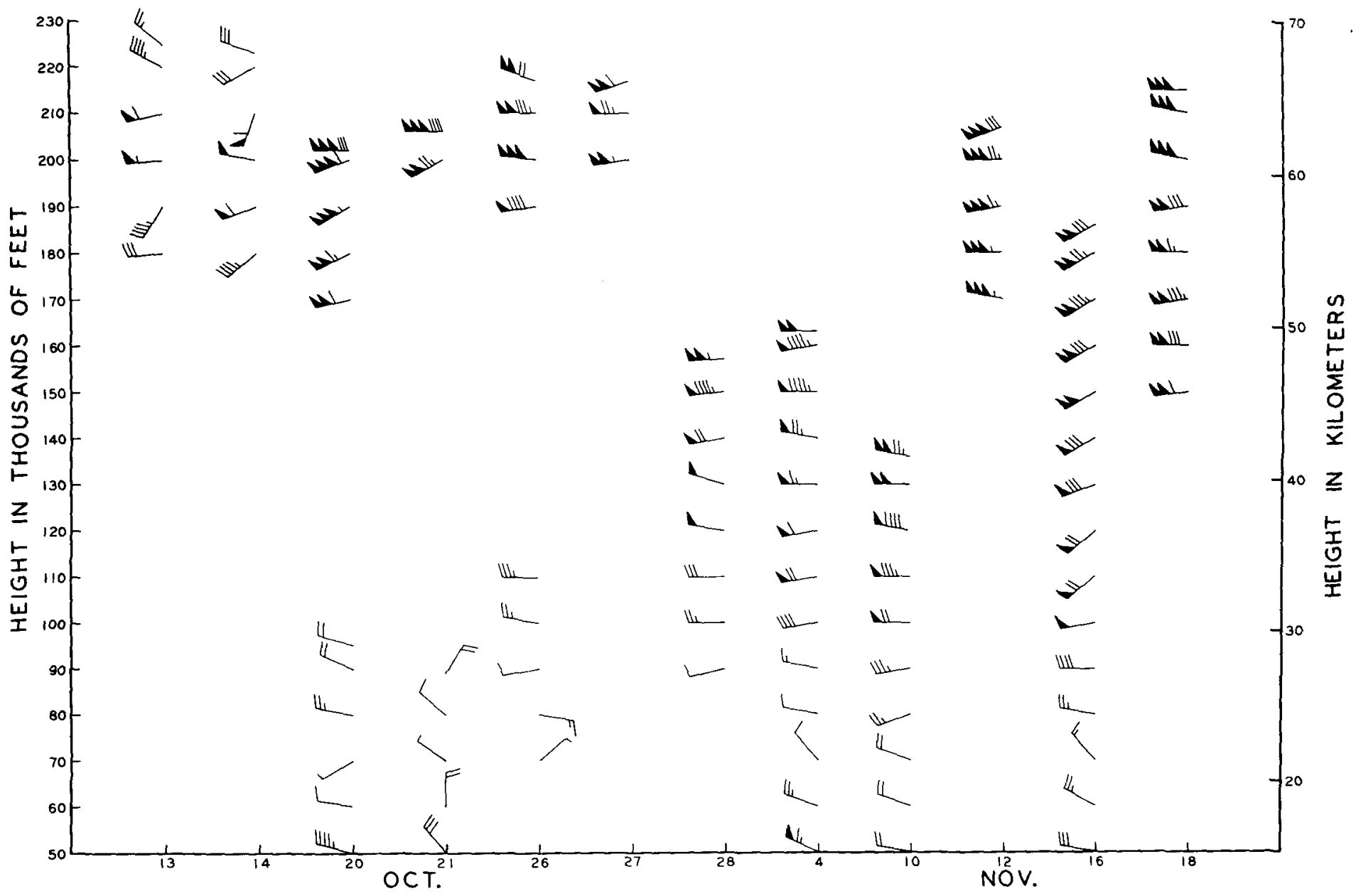

FIGURE 1.-Time cross section showing wind data obtained by rocketsonde in October and November 1959 series, Pacific Missile Range, Point Mugu, Calif.

Table 1.-Meteorological rocket summary. Pacific Missile Range, Point Mugu, Calif.

\begin{tabular}{|c|c|c|c|c|c|c|c|c|}
\hline \multicolumn{4}{|c|}{ Fall series } & \multicolumn{5}{|c|}{ Winter series } \\
\hline \multirow{2}{*}{ Date } & \multirow{2}{*}{ Vehicle } & Peak altitude & $\begin{array}{l}\text { Interval } \\
\text { sampled }\end{array}$ & \multirow{2}{*}{ Date } & \multirow[t]{2}{*}{ Vehicle } & & Peak altitude & $\begin{array}{l}\text { Interval } \\
\text { sampled }\end{array}$ \\
\hline & & \multicolumn{2}{|c|}{ (Thousands of feet) } & & & \multicolumn{3}{|c|}{ (Thousands of feet) } \\
\hline & LOKI II. & & $225-178$ & Jan. $15,1960 \ldots$ & LOKI I & & & $114-50$ \\
\hline Oct. 14, 1959.-. & $\begin{array}{l}\text { LOKI II- } \\
\text { LOTI }\end{array}$ & $227 \ldots \ldots$ & $223-173$ & Jan. $18,1960-$ & ARCAS & 19 & & $176-54$ \\
\hline Oct. $20,1959 \ldots$ & LOKI II- & unknown & $201-170$ & $\operatorname{Tan} 21,1960$ & LOKI I & 11 & & $110-58$ \\
\hline Oct. $20,1959$. & LOKI I & $116 \ldots \ldots$ & $95-50$ & Jan. $22,1960 \ldots$ & ARCAS & & & $173-48$ \\
\hline Oct. 21,1959 & LOKI II & $210 \ldots$ & $206-192$ & Jan. 25,1960 & LOKI II & & lown & $212-163$ \\
\hline Oct. 21,1959 & LOKI I & $102 \ldots \ldots$ & $102-27$ & Jan. 26,1960 & LOKI I. & 12 & & $104-50$ \\
\hline Oet. 26,1959 & LOKI II- & unknown & $218-189$ & Jan. 28,1960 & LOKI I & 11 & & $111-50$ \\
\hline Oct. 26, 1959- & LOKI I & unknown - & $115-70$ & Feb. 1, 1960--- & ARCAS & 15 & & $116-36$ \\
\hline Oct. $27,1959--$ & LOKO II & unknown & $215-190$ & Feb. 3,1960 & LOKA & 11 & & $\begin{array}{l}110-70) \\
144-4 !\end{array}$ \\
\hline $\begin{array}{l}\text { Uev. } \\
\text { Nov. 4, } 1959-\end{array}$ & ARCAS & 195 & $163-40$ & Feb. 4, 1960_- & ARCAS & 18 & & $\begin{array}{l}144-41 \\
160-85\end{array}$ \\
\hline Nov. 10,1959 & ARCAS & & $136-43$ & Feb. 5. 1960 & ARCAS & 14 & & $138-40$ \\
\hline Nov. 12, 1959- & LOKI II. & $220-$ & $207-165$ & Feb. 8, 1960 & ARCAS & & & $162-23$ \\
\hline \multirow{2}{*}{ Nov. 18,1959} & $\begin{array}{l}\text { ARCAS } \\
\text { LOKI I - }\end{array}$ & $217 \ldots$ & $\begin{array}{l}186-48 \\
215-148\end{array}$ & $\begin{array}{l}\text { Feb.11, 1960)- } \\
\text { Feb. 15, 1960). }\end{array}$ & & 20 & & $\begin{array}{l}114-49 \\
183-46\end{array}$ \\
\hline & & & & $\begin{array}{l}\text { Feb. 16, } 1960 \\
\text { Feb. }\end{array}$ & $\begin{array}{l}\text { ARCAS } \\
\text { ARCAS }\end{array}$ & & & $\begin{array}{l}150-45 \\
196-47\end{array}$ \\
\hline
\end{tabular}




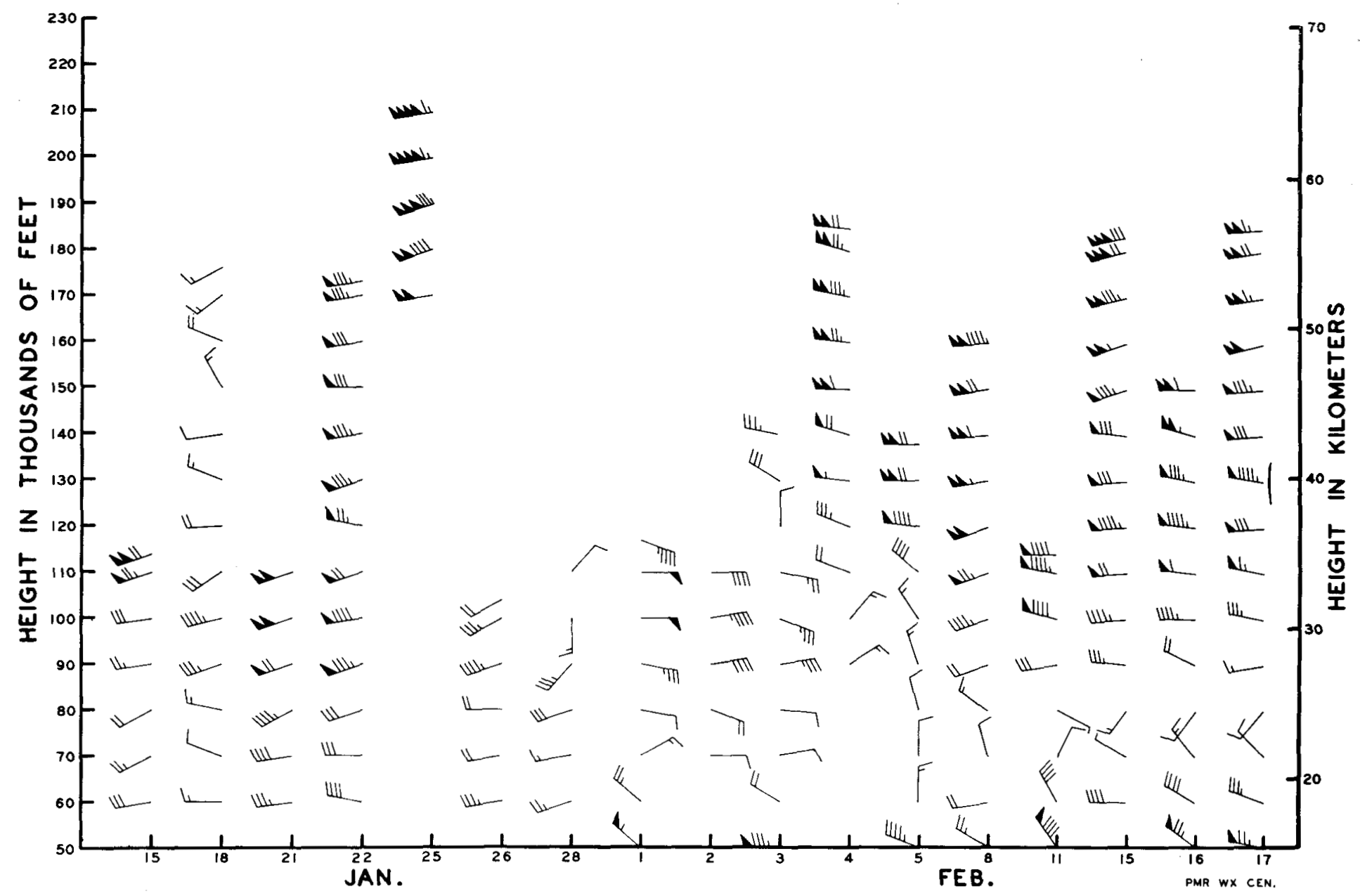

Figlre 2.- Time cross section showing wind data obtained by rocketsonde in January and February 1960 series, Point Mugu, Calif.

soundings over $210,000 \mathrm{ft}$. indicate a decrease in speed above that height.

Fortunately, Point Mugu is located at the same latitude as that estimated for the mesospheric jet core. There is a striking resemblance between the profile shown in figure 3 and the distribution postulated by Pant [2].

\section{CONCLUSION}

The fall and winter series of firings have provided a large amount of wind data in regions beyond the capability of balloons. Instrumental difficulties, primarily with sensors, have precluded collections of equal amounts of temperature data up to $200,000 \mathrm{ft}$. Some soundings are available [3] however, and more are expected from an improved instrument package being developed at Point Mugu. The next in the series of seasonal launches, the spring series, will take place during April and May of 1960 .

Data derived from rockets fired from each of the stations in the network are being forwarded to the U.S. Army

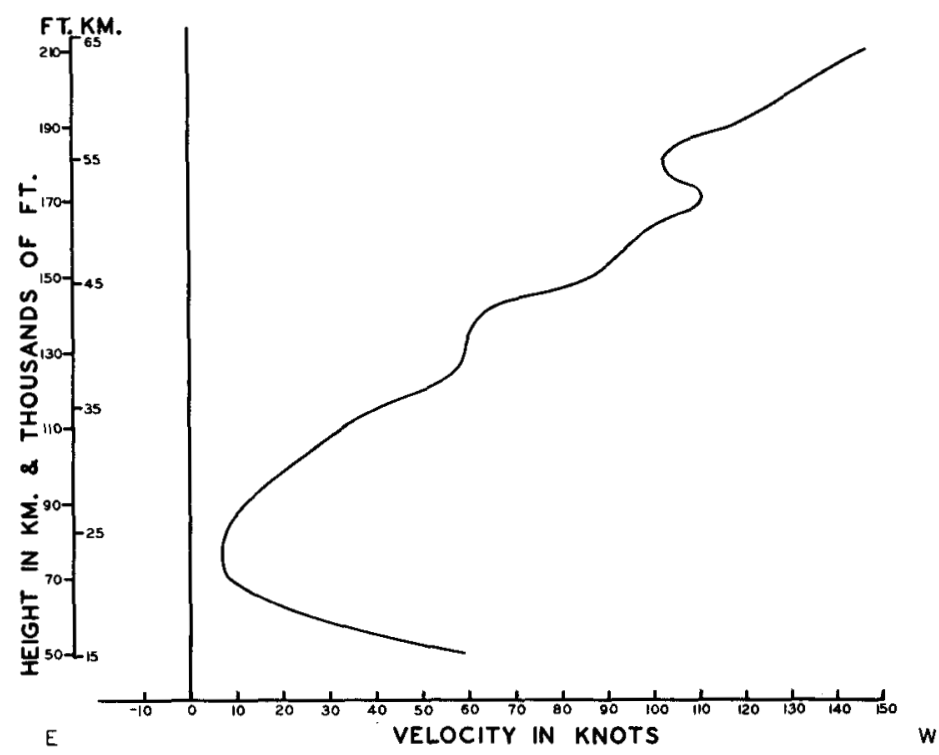

Figure 3.- Mean zonal wind, Point Mugu, Calif., obtained from data for fall and winter 1959-60 meteorological rocket program. 
Signal Missile Support Agency, White Sands Missile Range, N. Mex., for evaluation and further dissemination to interested research groups.

As a result of improved ARCAS hardware, it will soon be possible to increase the rocketsonde capability to approximately $300,000 \mathrm{ft}$. This will undoubtedly divulge data which will further whet the appetites of meteorologists for more information to aid in an understanding of the structure of the upper reaches of the atmosphere.

\section{REFERENCES}

1. W. L. Webb, W. E. Hubert, R. L. Miller, and J. F. Spurling, "Initiation of Meteorological Rocket Network," to be presented at the 187th National Meeting, American Meteorological Society, Eugene, Oreg., June 14-16, 1960.

2. P. S. Pant, "Circulation in the Upper Atmosphere," Scientific Report No. 1 on Contract No. AF19(604)-1006, New York University, May 1955.

3. D. E. Ogden and D. B. Swinton, "ARCAS Temperature Data in the Mesosphere," Monthly Weather Review, vol. 88, No. 5, May 1960, pp. 191-192. 